IJBPAS, August, Special Issue, 2021, 10(8): 457-470

ISSN: 2277-4998

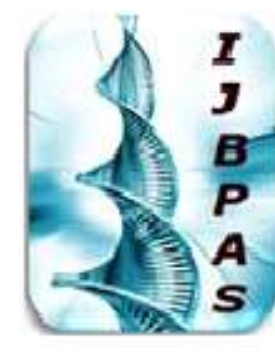

International Journal of Biology, Pharmacy

and Allied Seiences (IJBPAS)

'A Bridge Betusen Caboratory and Qundo'

WwW.ijbpas.com

\title{
STUDY ON RISK OF BACTERIAL CONTAMINATION IN BUBBLE TOP DRINKING WATER USED BY COMMUNITY
}

\author{
DIVYA DHARSHINI. A ${ }^{1}$ AND MURALIDHARAN. N.P ${ }^{2^{*}}$
}

1: Saveetha Dental College, Saveetha Institute of Medical And Technical Sciences, Saveetha University, Chennai, Tamil Nadu, 600077

2: Associate Professor, Department of Microbiology, Saveetha Dental College, Saveetha Institute of Medical And Technical Sciences, Saveetha University, Chennai, Tamil Nadu, 600077

*Corresponding Author: E Mail: Dr. N.P. Muralidharan: muralidharan@saveetha.com

Received 19 ${ }^{\text {th }}$ March 2021; Revised 20 ${ }^{\text {th }}$ April. 2021; Accepted $19^{\text {th }}$ May 2021; Available online $1^{\text {st }}$ Aug. 2021

https://doi.org/10.31032/IJBPAS/2021/10.8.1033

\begin{abstract}
To assess the bacterial load in bubble top water and check its compliance with Indian and international standards. Safe drinking water is a fundamental need of human life. It is generally believed that bottled water is safe for usage without any additional processing methods. For long-distance travelers, it serves as the only source of reliable drinking water. Several authors have reported that bottled water does not always meet the acceptability standards. In this study 15 samples of different brands of bubble top drinking water were collected in a sterile disposable plastic container. From each sample collected $5 \mathrm{ml}$ of water was centrifuged and the supernatant was discarded. From the sediment $50 \mu \mathrm{l}$ was transferred to Nutrient agar and MacConkey agar. Using a sterile inoculation loop, the drop was spread on the entire plate on both the agar. The Nutrient agar and MacConkey agar plates were incubated at $37^{\circ} \mathrm{c}$, aerobically for 24 hours. In this study, 15 water samples were analyzed. In all the 15 samples the bacterial load is found to be very high and shockingly above than any prescribed standard. The quantity of bacteria in Nutrient agar was to the extreme while the MacConkey agar indicates the presence of coliform
\end{abstract}


bacteria in the bubble top water. According to this study, none of the bottled drinking water manufacturers are maintaining any standards in providing clean and safe drinking water for human consumption. Surveillance of bottled water manufacturing industries in the settings on a regular basis needs to be done by regulatory agencies. These measures will ensure safe and wholesome bottled water for public usage.

Keywords: Bottled drinking water, bacterial load, Human consumption, Surveillance INTRODUCTION

In a country where the major population depends on rain water for all the utility and drinking, water becomes an issue. When the river connectivity is poor and the groundwater recharge is insufficient, the ground water quality will be poor and will not be potable. In this situation, a major population depends on pre-treated water, which is convenient for consumption (ElHarouny et al., 2008). There are standards set for manufacture, storage and distribution of ready to use drinking water. But in developing countries, the regulatory mechanism and the monitoring systems are seldom evident or implemented. This becomes a major health problem even in day to day living in the community (Belkouteb et al., 2020). This study is done to explore the major risk factor, the bacterial load in such bottled drinking water.

Bubble top water is usually regarded as safe for usage by people. It serves as the only reliable source of drinking water available for long-distance travelers (Edema, Atayese and Bankole, 2011). Bubble top water production companies are one of the fastest growing industrial sectors in this part of the world. Recently, there are more than 3000 bottling plants in India. Mostly, the manufacturing companies of bubble top water in India according to previous study are located in unhygienic locations like agricultural fields or estates and most companies use bore wells or pump or canal water as source of water. Here, water is pumped out from depths varying from 80 to 500 feet below from the ground which would contain more contaminants (Finlayson, 2011) (Ashwin and Muralidharan, 2015). Few sources of bubble top water are collected from public drinking water systems such as Municipality supply water (Dege, 2011). Ground water would have quality problems due to salinity and contaminants like agrochemicals, nitrates, fluoride, iron etc (Goncharuk, 2014; Girija As and Priyadharsini J, 2019). The ground water available in half of the districts in our 
country was found to be unfit for drinking. This was because of the presence of contaminants exceeding the limiting levels of the Indian or international standards (Saravanan, 2013) (Gangil et al., 2013).

Studies done in India and other parts of the world have reported that bottled water was contaminated or polluted with harmful disease-causing microorganisms at various stages of its production (Kassenga, 2007; Semerjian, 2011). Consumption of bubble top contaminated drinking water has led to frequent outbreaks of waterborne diseases such as cholera, typhoid, and hepatitis etc. (Ahmed et al., 2020) (Girija et al., 2019).

The microbiological qualities of bubble top drinking water of some manufacturers have been found to be in greater violation with Indian and international standards. According to the Central Ground Water Board, BIS (IS_10500 and revised module IS 10500:2012) has specifications in Uniform Drinking Water Quality Monitoring Protocol. This standard has two limits i.e. acceptable limits and permissible limits in the absence of an alternate source. If any parameter exceeds the limit, the water is considered unfit for human consumption (Selvakumar and Np, 2017). According to BIS , E- coli or thermotolerant coliform bacteria and total bacterial count shall not be detectable in any
$100 \mathrm{ml}$ of sample ('A response to the Institute of Food Technology Annual Meeting in New Orleans 16-20 July, 2005', 2006).

Water is a very sensitive product. One of the main challenges of bubble top water processing is to produce a quality product free of pathogenic organisms and protozoa (Shahana and Muralidharan, 2016) (Marickar, Geetha and Neelakantan, 2014). Strict production control is critical to avoid any contamination of pathogenic bacteria or protozoa. As per International standards of drinking water by WHO, the drinking water should possess a TDS of less than $500 \mathrm{mg} / \mathrm{l}$, zero toxic elements and disease causing bacterial population. Bubble top water processing includes Water filtration, Tank Venting, Carbonation, Bottle Blower and Bottle Washer \& Bottle Filler. Water is also treated with Chlorine, which kills harmful bacteria and some viruses and also protects the water from recontamination while storing. EPA mandates that chlorine level in drinking water should be not higher than 4 milligrams per litre. EPA says fluoridation also provides some protection against skeletal fluorosis, a painful joint condition (Schweisfurth and Schweisfurth, 2013). Significant levels of pesticides like organochlorine compounds and 
organophosphorus compounds have been reported in freshwater systems and in the bubble top water samples collected from some major cities in India (Louie and Reuschlein, 2011).

One of the most common flocculants used in water purification is aluminum sulfate which is also known as alum. Alum is a coagulant that helps to settle down all floating suspended solids and colloidal substances present in water (Huser, Brezonik and Newman, 2011) (Pratha, Ashwatha Pratha and Geetha, 2017). Alum is added to drinking water to remove the microorganisms like viruses, bacteria and protozoa present in the water. At low levels, these organisms can cause sickness and diseases. In contrast, aluminum sulphate in water can be absorbed by humans because after water treatment the aluminum is largely in an unbound form. At low levels aluminum in food, air and water is not harmful to our health, but with long term regular exposure, there is evidence linking aluminum to effects on the nervous system, with possible connections to several diseases, such as Parkinson's, Alzheimer's and Lou Gehrig's disease (Vaishali and Geetha, 2018) (M, Geetha and Thangavelu, 2019). Patients suffering from these diseases tend to have high levels of aluminum in some areas of their brains. There is no evidence to suggest that aluminum affects reproduction or it causes cancer (Mohamed et al., 2020).

Despite the common belief that bubble water is safer to drink and has better taste than tap water, scientific studies have shown that the belief is not necessarily true (Raj, 2005). Research also shows that the sales and consumption of bubble water can have environmental and social impacts whose consequences are yet to be fully understood (Opel, 1999) (Paramasivam, Vijayashree Priyadharsini and Raghunandhakumar, 2020). We store water in all sorts of plastic bottles, jugs or containers. It can be below grade or high grade, but plastic is plastic (Priyadharsini et al., 2018a). This is a very harmful daily practice as plastic containers carry a lot of chemicals and bacteria that would result in Stunted growth, Early puberty, Premature birth, Infertility, Early menopause, Diabetes, Heart disease, Cancer. Previously our team has a rich experience in working on various research projects across multiple disciplines. (Muthukrishnan and Warnakulasuriya, 2018), (Govindaraju, Neelakantan and Gutmann, 2017), (Chen et al., 2019), (Priyanka et al., 2017), (Sitharthan et al., 2019), (Priyadharsini et al., 2018b), (Azeem and Sureshbabu, 2018), (Wu et al., 2019), (Abitha and Santhanam, 2019), (Manohar and 
Abilasha, 2019), (Venu, Dhana Raju and Subramani, 2019), (Wang et al., 2019), (S. A. Girija, Jayaseelan and Arumugam, 2018), (Sheriff, Ahmed Hilal Sheriff and Santhanam, 2018), (Dhinesh et al., 2017) Now the growing trend in this area motivated us to pursue this project.

These observations imply that bubble top drinking water is insufficient to have safe water for consumption. Hence, periodic surveillance of packaged drinking water like bubble top water is very much essential. This will serve the dual purpose of monitoring the standards of bottled water production industries as well as help in giving reassurance of quality to users. Hence, To assess the bacteriological quality of bubble top water and check its compliance with Indian and international standards.

\section{MATERIALS AND METHOD}

In this study, 15 samples of different brands of bubble top drinking water from different places were collected in a sterile disposable closed plastic container. As soon as the water samples are collected in the disposable plastic container, it is stored in the refrigerator till the next step of the centrifugation process is done. From each sample collected, $5 \mathrm{ml}$ of water was centrifuged and the supernatant was discarded. From the sediment $50 \mu 1$ each was transferred to Nutrient agar and MacConkey agar. Using a sterile inoculation loop, the drop was spread on the entire plate on both the nutrient and Mac Conkey agar. Thereafter both the plates were incubated at $37^{\circ} \mathrm{C}$ aerobically for 24 hours.

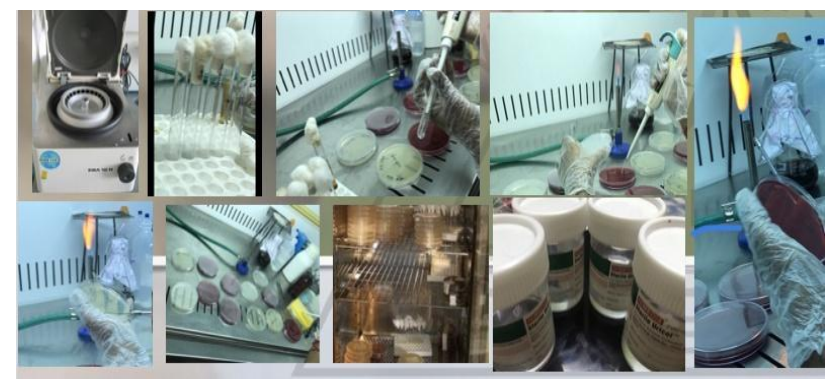

RESULTS AND DISCUSSION

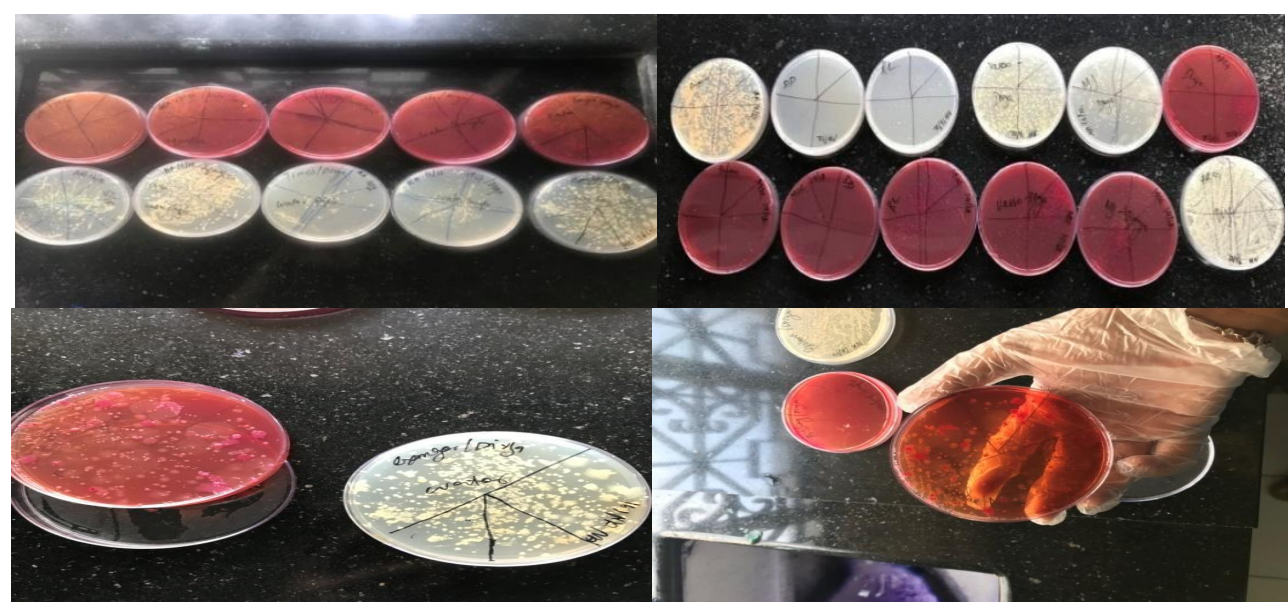

Figure 1: Presence of total bacterial count in Nutrient agar and presence of Coliform bacteria in Mac Conkey agar 
Table 1: Total number of bacterial counts in both the agar per $100 \mathrm{ml}$ of different 15 samples of bubble top water

\begin{tabular}{|c|c|c|}
\hline Sample No. & Total count $/ \mathbf{1 0 0} \mathbf{~ m l}$ & Coliform/ $\mathbf{1 0 0} \mathbf{~ m l}$ \\
\hline $\mathbf{1}$ & $\mathbf{8 0 0 0}$ & $\mathbf{2 4 0 0}$ \\
\hline $\mathbf{2}$ & $\mathbf{4 0 0 0 0}$ & $\mathbf{1 6 8 0 0}$ \\
\hline 3 & $\mathbf{2 4 0 0 0}$ & $\mathbf{2 2 5 0 0}$ \\
\hline 4 & $\mathbf{6 8 0 0 0}$ & $\mathbf{2 4 8 0 0}$ \\
\hline 5 & $\mathbf{7 4 0 0 0}$ & $\mathbf{7 0 0 0 0}$ \\
\hline 6 & $\mathbf{7 5 0 0}$ & $\mathbf{5 0 0 0}$ \\
\hline 7 & $\mathbf{3 6 0 0 0}$ & $\mathbf{3 2 5 0 0}$ \\
\hline 8 & $\mathbf{7 2 0 0 0}$ & $\mathbf{4 0 0 0 0}$ \\
\hline 9 & $\mathbf{5 1 2 0 0}$ & $\mathbf{2 5 0 0 0}$ \\
\hline 10 & $\mathbf{2 1 0 0 0}$ & $\mathbf{1 8 0 0 0}$ \\
\hline 11 & 15000 & $\mathbf{8 0 0}$ \\
\hline 12 & $\mathbf{2 5 0 0 0}$ & $\mathbf{1 0 0 0}$ \\
\hline 13 & $\mathbf{1 2 8 0 0}$ & $\mathbf{1 6 0 0}$ \\
\hline 14 & $\mathbf{8 0 0 0}$ & $\mathbf{4 0 0 0}$ \\
\hline 15 & $\mathbf{7 2 0 0 0}$ & $\mathbf{1 6 0 0}$ \\
\hline
\end{tabular}

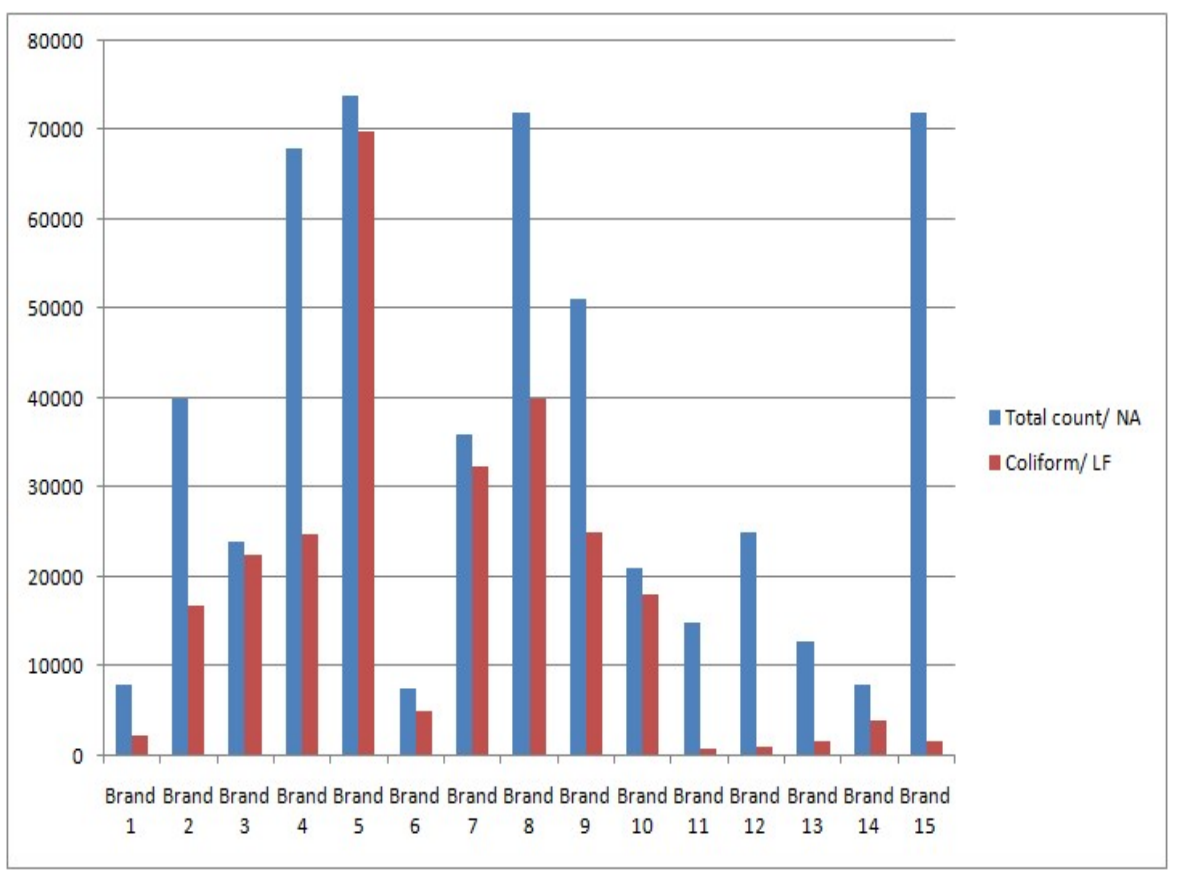

Figure 2: This bar graph represents the total number of CFU coliform bacterial count per $100 \mathrm{ml}$ of 15 different samples of bubble top water

Bubble top Drinking water was not upto the specific limit as specified by Indian and international standard of drinking water. There is a limit for number and kinds of organisms permissible in drinking water according to the $\mathrm{WHO}$ and international standards (Priyadharsini et al., 2018b). The acceptability of the water quality was determined based on the total bacterial load in the water and the presence of coliforms, indicator organisms and other physical and chemical parameters (S. A. S. Girija, Jayaseelan and Arumugam, 2018). 
In this study, 15 water samples were analyzed. In all the 15 samples the bacterial load is found to be very high and shockingly above than any prescribed standard. The quantity of bacteria in Nutrient agar was to the extreme while the MacConkey agar indicates the presence of coliform bacteria in the bottled water, means that the pathogens are present. Most pathogens that can contaminate water come from human and animal feces (Shahzan et al., 2019). The presence of these organisms, even when they are non pathogenic is also of greater risk in immunocompromised persons where it could cause opportunistic infections. Such persons include young children, elderly peoples, pregnant women, people with cancer, diabetes and people on medications as the corticosteroids which possess immunosuppressive properties (Bartram et al., 2003). It has been pointed out that high numbers of heterotrophic bacteria in bubble top water might arise when unsterilized or uncapped plastic bottles are transported to bottling plants which would expose the interiors of the bottles to airborne contaminants (Smiline, Vijayashree and Paramasivam, 2018) and it is an indication of poor manufacturing practices involved in the processing of such water (Ibrahim, Mohammed and Hafez, 2014).
The observation from this study is an indication of the lack of required infrastructure and Requirements such as clean rooms, automatic bottle filling machines, clean water source, trained personnel and the need for staff supervision by personnel who are knowledgeable in water purification and dispensing must be met by companies who are involved in the production of packaged water for human consumption. This implies that the capital needed by a particular water bottling company in order to put all these things in place must be quite good. From the consumer side, Ensure whether it is properly sealed with details like manufactures name,BIS and FSSAI license number. These can be cross checked by the consumer on clean drinking water portal and the label on the seal and body should also carry the packing date and batch number. Our institution is passionate about high quality evidence based research and has excelled in various fields (Pc, Marimuthu and Devadoss, 2018; Ramesh et al., 2018; Vijayashree Priyadharsini, Smiline Girija and Paramasivam, 2018; Ezhilarasan, Apoorva and Ashok Vardhan, 2019; Ramadurai et al., 2019; Sridharan et al., 2019; Vijayashree Priyadharsini, 2019; Chandrasekar et al., 2020; Mathew et al., 2020; $\mathrm{R}$ et al., 2020; 
Samuel, 2021). We hope this study adds to this rich legacy.

\section{CONCLUSION}

According to this study, none of the bubble top drinking water manufacturers are maintaining any standards in providing clean and safe drinking water for human consumption. There is a need for a rigorous inspection and follow-up of water bottling facilities so that only those companies which consistently produce water with acceptable bacteriological index are allowed to produce water for public consumption. Surveillance of bubble top water manufacturing industries in the settings on a regular basis needs to be done by regulatory agencies. These measures will ensure safe and wholesome water for public usage.

\section{CONFLICT OF INTEREST}

No potential conflict of interest relevant to this article was reported.

\section{ACKNOWLEDGEMENT}

The authors are grateful to Saveetha Dental College for providing a platform to express our knowledge.

\section{REFERENCES}

[1] Abitha, T. and Santhanam, A. (2019) 'Correlation between bizygomatic and maxillary central incisor width for gender identification', Brazilian Dental Science. Available at: https://bds.ict.unesp.br/index.php/cob/arti cle/view/1775

[2] Ahmed, J. et al. (2020) 'Quantitative Microbial Risk Assessment of Drinking Water Quality to Predict the Risk of Waterborne Diseases in Primary-School Children', International journal of environmental research and public health, 17(8). doi: 10.3390/ijerph17082774.

[3] 'A response to the Institute of Food Technology Annual Meeting in New Orleans 16-20 July, 2005' (2006) Food Hydrocolloids, pp. 548-549. doi: 10.1016/j.foodhyd.2005.09.001.

[4] Ashwin, K. S. and Muralidharan, N. P. (2015)

'Vancomycin-resistant enterococcus (VRE) vs Methicillinresistant Staphylococcus Aureus (MRSA)', Indian Journal of Medical Microbiology, p. 166. doi: 10.4103/02550857.150976.

[5] Azeem, R. A. and Sureshbabu, N. M. (2018) 'Clinical performance of direct versus indirect composite restorations in posterior teeth: A systematic review', Journal of conservative dentistry: JCD, 21(1), pp. 2-9. doi: 10.4103/JCD.JCD_213_16.

[6] Bartram, J. et al. (2003) Heterotrophic Plate Counts and Drinking-water Safety. IWA Publishing. Available at: https://books.google.com/books/about/H eterotrophic_Plate_Counts_and_Drinkin g.html?hl=\&id=HQx8a_KtBbAC. 
[7] Belkouteb, N. et al. (2020) 'Removal of per- and polyfluoroalkyl substances (PFASs) in a full-scale drinking water treatment plant: Long-term performance of granular activated carbon (GAC) and influence of flow-rate', Water research, 182, p. $115913 . \quad$ doi: 10.1016/j.watres.2020.115913.

[8] Chandrasekar, R. et al. (2020) 'Development and validation of a formula for objective assessment of cervical vertebral bone age', Progress in orthodontics, 21(1), p. $38 . \quad$ doi: 10.1186/s40510-020-00338-0.

[9] Chen, F. et al. (2019) '6-shogaol, a active constiuents of ginger prevents UVB radiation mediated inflammation and oxidative stress through modulating $\mathrm{NrF} 2$ signaling in human epidermal keratinocytes (HaCaT cells)', Journal of photochemistry and photobiology. B, Biology, 197, p. 111518. doi: 10.1016/j.jphotobiol.2019.111518.

[10] Dege, N. (2011) 'Categories of Bottled Water', Technology of Bottled Water, pp. 33-97. doi: 10.1002/9781444393330.ch3.

[11] Dhinesh, B. et al. (2017) 'An experimental analysis on the influence of fuel borne additives on the single cylinder diesel engine powered by Cymbopogon flexuosus biofuel', Journal of the Energy Institute, 90(4), pp. 634-645. doi: 10.1016/j.joei.2016.04.010.

[12] Edema, M. O., Atayese, A. O. and Bankole, M. O. (2011) 'Pure water syndrome: Bacteriological quality of Sachet- packed drinking water sold in Nigeria', African Journal of Food, Agriculture, Nutrition and Development. doi: 10.4314/ajfand.v11i1.65885.

[13] El-Harouny, M. et al. (2008) 'Chemical Quality of Tap Water Versus Bottled Water: Evaluation of Some Heavy Metals and Elements Content of Drinking Water in Dakahlia Governorate - Egypt', Mansoura Journal of Forensic Medicine and Clinical Toxicology, pp. 1-15. doi: 10.21608/mjfmct.2008.54090.

[14] Ezhilarasan, D., Apoorva, V. S. and Ashok Vardhan, N. (2019) 'Syzygium cumini extract induced reactive oxygen species-mediated apoptosis in human oral squamous carcinoma cells', Journal of oral pathology \& medicine: official publication of the International Association of Oral Pathologists and the American Academy of Oral Pathology, 48(2), pp. 115-121. doi: 10.1111/jop. 12806 .

[15] Finlayson, D. (2011) 'Market Development of Bottled Waters', Technology of Bottled Water, pp. 5-31. doi: 10.1002/9781444393330.ch2.

[16] Gangil, R. et al. (2013) 'Bacteriological 
evaluation of packaged bottled water sold at Jaipur city and its public health significance', Veterinary World, p. 27. doi: 10.5455/vetworld.2013.27-30.

[17] Girija, A. S. S. et al. (2019) 'Plasmidencoded resistance to trimethoprim/sulfamethoxazole mediated by dfrA1, dfrA5, sul1 and sul2 among Acinetobacter baumannii isolated from urine samples of patients with severe urinary tract infection', Journal of Global Antimicrobial Resistance, pp. 145-146. doi: 10.1016/j.jgar.2019.04.001.

[18] Girija As, S. and Priyadharsini J, V. (2019) 'CLSI based antibiogram profile and the detection of MDR and XDR strains of Acinetobacter baumannii isolated from urine samples', Medical journal of the Islamic Republic of Iran, 33, p. 3. doi: 10.34171/mjiri.33.3.

[19] Girija, S. A., Jayaseelan, V. P. and Arumugam, P. (2018) 'Prevalence of VIM- and GIM-producing Acinetobacter baumannii from patients with severe urinary tract infection', Acta microbiologica et immunologica Hungarica, 65(4), pp. 539-550. doi: 10.1556/030.65.2018.038.

[20] Girija, S. A. S., Jayaseelan, V. P. and Arumugam, P. (2018) 'Prevalence of VIM- and GIM-producing Acinetobacter baumannii from patients with severe urinary tract infection',
Acta Microbiologica et Immunologica Hungarica, pp. 539-550. doi: 10.1556/030.65.2018.038.

[21] Goncharuk, V. V. (2014) 'Drinking Water: Factors Affecting the Quality of Drinking Water', Drinking Water, pp. 105-245. doi: 10.1007/978-3-31904334-0_4.

[22] Govindaraju, L., Neelakantan, P. and Gutmann, J. L. (2017) 'Effect of root canal irrigating solutions on the compressive strength of tricalcium silicate cements', Clinical oral investigations, 21(2), pp. 567-571. doi: 10.1007/s00784-016-1922-0.

[23] Huser, B., Brezonik, P. and Newman, R. (2011) 'Effects of alum treatment on water quality and sediment in the Minneapolis Chain of Lakes, Minnesota, USA', Lake and Reservoir Management, pp. 220-228. doi: 10.1080/07438141.2011.601400.

[24] Ibrahim, H. Z., Mohammed, H. A. G. and Hafez, A. M. (2014) 'Physicochemical properties of some bottled water brands in Alexandria Governorate, Egypt', Journal of the Egyptian Public Health Association, pp. 60-65. doi: 10.1097/01.epx.0000451919.21292.8a.

[25] Kassenga, G. R. (2007) 'The healthrelated microbiological quality of bottled drinking water sold in Dar es Salaam, Tanzania', Journal of Water 
and Health, pp. 179-185. doi: 10.2166/wh.2006.052.

[26] Louie, W. and Reuschlein, D. (2011) 'Cleaning and Disinfection in the Bottled Water Industry', Technology of Bottled Water, pp. 223-266. doi: 10.1002/9781444393330.ch8.

[27] Manohar, J. and Abilasha, R. (2019) 'A Study on the Knowledge of Causes and Prevalance of Pigmentation of Gingiva among Dental Students', Indian Journal of Public Health Research \& Development, p. 95. doi: 10.5958/09765506.2019.01859.x.

[28] Marickar, R. F., Geetha, R. V. and Neelakantan, P. (2014) 'Efficacy of Contemporary and Novel Intracanal Medicaments againstEnterococcus Faecalis', Journal of Clinical Pediatric Dentistry, pp. 47-50. doi: 10.17796/jcpd.39.1.wmw9768314h566 66.

[29] Mathew, M. G. et al. (2020) 'Evaluation of adhesion of Streptococcus mutans, plaque accumulation on zirconia and stainless steel crowns, and surrounding gingival inflammation in primary molars: Randomized controlled trial', Clinical oral investigations, pp. 1-6. Available at:

https://ink.springer.com/article/10.100 7/s00784-020-03204-9.

[30] M, M. A., Geetha, R. V. and
Thangavelu, L. (2019) 'Evaluation oEvaluation of anti-inflammatory action of Laurus nobilis-an in vitro studyf anti-inflammatory action of Laurus nobilis-an in vitro study', International Journal of Research in Pharmaceutical Sciences, pp. 12091213. doi: 10.26452/ijrps.v10i2.408.

[31] Mohamed, A. Y. A. et al. (2020) 'Appraisal and ranking of polyaluminium chloride, ferric chloride and alum for the treatment of dairy soiled water', Journal of environmental management, 267, p. 110567. doi: 10.1016/j.jenvman.2020.110567.

[32] Muthukrishnan,

A. and Warnakulasuriya, S. (2018) 'Oral health consequences of smokeless tobacco use', The Indian journal of medical research, 148(1), pp. 35-40. doi: 10.4103/ijmr.IJMR_1793_17.

[33] Opel, A. (1999) 'Constructing Purity: Bottled Water and the Commodification of Nature', The Journal of American Culture, pp. 67-76. doi: 10.1111/j.1542-734x.1999.2204_67.x.

[34] Paramasivam, A., Vijayashree Priyadharsini, J. and Raghunandhakumar, S. (2020) 'N6adenosine methylation (m6A): a promising new molecular target in hypertension and cardiovascular diseases', Hypertension research: official journal of the Japanese Society 
of Hypertension, 43(2), pp. 153-154. doi: 10.1038/s41440-019-0338-z.

[35] Pc, J., Marimuthu, T. and Devadoss, P. (2018) 'Prevalence and measurement of anterior loop of the mandibular canal using CBCT: A cross sectional study', Clinical implant dentistry and related research. Available at: https://europepmc.org/article/med/2962 4863.

[36] Pratha, A. A., Ashwatha Pratha, A. and Geetha, R. V. (2017) 'Awareness on Hepatitis-B vaccination among dental students-A Questionnaire Survey', Research Journal of Pharmacy and Technology, p. 1360. doi: 10.5958/0974-360x.2017.00240.2.

[37] Priyadharsini, J. V. et al. (2018a) 'An insight into the emergence of Acinetobacter baumannii as an orodental pathogen and its drug resistance gene profile - An in silico approach', Heliyon, p. e01051. doi: 10.1016/j.heliyon.2018.e01051.

[38] Priyadharsini, J. V. et al. (2018b) 'In silico analysis of virulence genes in an emerging dental pathogen A. baumannii and related species', Archives of Oral Biology, pp. 93-98. doi: 10.1016/j.archoralbio.2018.07.001.

[39] Priyanka, S. et al. (2017) 'Detection of cytomegalovirus, Epstein-Barr virus, and Torque Teno virus in subgingival and atheromatous plaques of cardiac patients with chronic periodontitis', Journal of Indian Society of Periodontology, 21(6), pp. 456-460. doi: 10.4103/jisp.jisp_205_17.

[40] Raj, S. D. (2005) 'Bottled Water: How Safe Is It?', Water Environment Research, pp. 3013-3018. doi: $10.2175 / 106143005 \times 73893$.

[41] Ramadurai, N. et al. (2019) 'Effectiveness of 2\% Articaine as an anesthetic agent in children: randomized controlled trial', Clinical oral investigations, 23(9), pp. 35433550. doi: 10.1007/s00784-018-2775-5.

[42] Ramesh, A. et al. (2018) 'Comparative estimation of sulfiredoxin levels between chronic periodontitis and healthy patients - A case-control study', Journal of periodontology, 89(10), pp. 1241-1248. doi: 10.1002/JPER.170445 .

[43] R, H. et al. (2020) 'CYP2 C9 polymorphism among patients with oral squamous cell carcinoma and its role in altering the metabolism of benzo[a]pyrene', Oral Surgery, Oral Medicine, Oral Pathology and Oral Radiology, pp. 306-312. doi: 10.1016/j.oooo.2020.06.021.

[44] Samuel, S. R. (2021) 'Can 5-year-olds sensibly self-report the impact of developmental enamel defects on their quality of life?', International journal of paediatric dentistry / the British 
Paedodontic Society [and] the International Association of Dentistry for Children, 31(2), pp. 285-286. doi: 10.1111/ipd.12662.

[45] Saravanan, V. S. (2013) 'Urbanizing diseases: contested institutional terrain of water- and vector-borne diseases in Ahmedabad, India', Water International, pp. 875-887. doi: 10.1080/02508060.2013.851363.

[46] Schweisfurth and Schweisfurth (2013) 'Review Article: Prevalence and Health Effects of Water Pipe (Shisha) Tobacco Smoking', Global Journal of Pathology and Microbiology. doi: 10.14205/23108703.2013.01.02.5.

[47] Selvakumar, R. and Np, M. (2017) 'COMPARISON IN BENEFITS OF HERBAL MOUTHWASHES WITH CHLORHEXIDINE MOUTHWASH:

A REVIEW', Asian Journal of Pharmaceutical and Clinical Research, p. $3 . \quad$ doi: 10.22159/ajpcr.2017.v10i2.13304.

[48] Semerjian, L. A. (2011) 'Quality assessment of various bottled waters marketed in Lebanon', Environmental Monitoring and Assessment, pp. 275285. doi: 10.1007/s10661-010-1333-7.

[49] Shahana, R. Y. and Muralidharan, N. P. (2016) 'Efficacy of mouth rinse in maintaining oral health of patients attending orthodontic clinics', Research Journal of Pharmacy and Technology, p. 1991. doi: 10.5958/0974360x.2016.00406.6.

[50] Shahzan, M. S. et al. (2019) 'A computational study targeting the mutated L321F of ERG11 gene in C. albicans, associated with fluconazole resistance with bioactive compounds from Acacia nilotica', Journal de Mycologie Médicale, pp. 303-309. doi: 10.1016/j.mycmed.2019.100899.

[51] Sheriff, K. A. H., Ahmed Hilal Sheriff, K. and Santhanam, A. (2018) 'Knowledge and Awareness towards Oral Biopsy among Students of Saveetha Dental College', Research Journal of Pharmacy and Technology, p. 543. doi: 10.5958/0974360x.2018.00101.4.

[52] Sitharthan, R. et al. (2019) 'Automated power management strategy for wind power generation system using pitch angle controller', Measurement and Control, 52(3-4), pp. 169-182. doi: 10.1177/0020294019827330.

[53] Smiline, A. S. G., Vijayashree, J. P. and Paramasivam, A. (2018) 'Molecular characterization of plasmid-encoded blaTEM, blaSHV and blaCTX-M among extended spectrum $\beta$-lactamases [ESBLs] producing Acinetobacter baumannii', British Journal of Biomedical Science, pp. 200-202. doi: 10.1080/09674845.2018.1492207.

[54] Sridharan, G. et al. (2019) 'Evaluation 
of salivary metabolomics in oral leukoplakia and oral squamous cell carcinoma', Journal of oral pathology \& medicine: official publication of the International Association of Oral Pathologists and the American Academy of Oral Pathology, 48(4), pp. 299-306. doi: 10.1111/jop.12835.

[55] Vaishali, M. and Geetha, R. V. (2018) 'Antibacterial activity of Orange peel oil on Streptococcus mutans and Enterococcus-An In-vitro study', Research Journal of Pharmacy and Technology, p. 513. doi: 10.5958/0974360x.2018.00094.x.

[56] Venu, H., Dhana Raju, V. and Subramani, L. (2019) 'Combined effect of influence of nano additives, combustion chamber geometry and injection timing in a DI diesel engine fuelled with ternary (diesel-biodieselethanol) blends', Energy, pp. 386-406. doi: 10.1016/j.energy.2019.02.163.

[57] Vijayashree Priyadharsini, J. (2019) 'In silico validation of the non-antibiotic drugs acetaminophen and ibuprofen as antibacterial agents against red complex pathogens', Journal of periodontology, 90(12), pp. 1441-1448. doi: 10.1002/JPER.18-0673.

[58] Vijayashree Priyadharsini, J., Smiline Girija, A. S. and Paramasivam, A. (2018) 'In silico analysis of virulence genes in an emerging dental pathogen
A. baumannii and related species', Archives of oral biology, 94, pp. 93-98. doi: 10.1016/j.archoralbio.2018.07.001.

[59] Wang, Y. et al. (2019) 'Synthesis of Zinc oxide nanoparticles from Marsdenia tenacissima inhibits the cell proliferation and induces apoptosis in laryngeal cancer cells (Hep-2)', Journal of photochemistry and photobiology. B, Biology, 201, p. 111624. doi: 10.1016/j.jphotobiol.2019.111624.

[60] Wu, F. et al. (2019) 'Biologically synthesized green gold nanoparticles from Siberian ginseng induce growthinhibitory effect on melanoma cells (B16)', Artificial cells, nanomedicine, and biotechnology, 47(1), pp. 32973305 .

doi:10.1080/21691401.2019.1647224. 